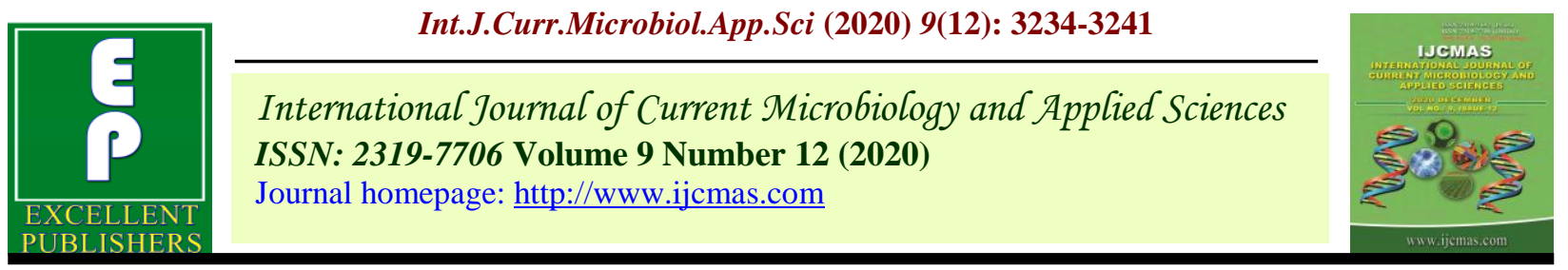

\title{
Genetic Variability Studies for Quantitative Traits in a Pool of Maintainer (B) and Restorer (R) Lines in Pearl Millet (Pennisetum glaucum (L.) R. Br.)
}

\author{
P. Saikumar ${ }^{1 *}$, M. Shanthi Priya ${ }^{2}$, P. Shanthi ${ }^{1}$ and P. Latha ${ }^{3}$ \\ ${ }^{1}$ Department of Genetics and Plant Breeding, S.V. Agricultural College, Tirupati, A.P, India \\ ${ }^{2}$ Department of Genetics and Plant Breeding, ARS, Perumallapalle, Tirupati, A.P, India \\ ${ }^{3}$ Department of Crop Physiology, IFT, RARS, Tirupati, A.P, India \\ *Corresponding author
}

\section{A B S T R A C T}

\begin{tabular}{|l|}
\hline K e y w o r d s \\
Pearl millet, \\
Genetic advance, \\
Heritability, \\
Variability
\end{tabular}

\begin{abstract}
The present investigation was carried out at Agricultural Research Station, Perumallapalle, Tirupati, A.P. with 10 maintainer (B) and 27 restorer (R) lines of pearl millet during summer, 2020 in randomized block design with three replications to estimate genetic parameters viz., genetic variance, heritability (broad sense) and genetic advance as per cent of mean for 15 quantitative traits. The analysis of variance revealed highly significant differences among the genotypes for all the characters studied. The phenotypic coefficient of variation (PCV) was higher than genotypic coefficient of variation (GCV) and the difference between PCV and GCV was narrow for most of the characters, implying little influence of environment on expression of the traits. High values of PCV, GCV and heritability estimates coupled with maximum genetic advance over mean were obtained for panicle length, green fodder yield per plant, dry fodder yield per plant, panicle weight, 1000 grain weight, harvest index and grain yield per plant indicating the preponderance of additive gene action and selection based on these characters could be effective.
\end{abstract}

\section{Introduction}

Pearl millet (Pennisetum glaucum (L.) R. Br.) is diploid $(2 \mathrm{n}=14)$ and highly cross pollinated, annual $\mathrm{C}_{4}$ crop which belongs to the family of poaceae. It is originated in central tropical Africa and is cosmopolitan within arid and semi-arid topics of Africa and India. It is commonly known as cumbu or dark millet or spiked millet or candle millet. It has protogyny and anemophily mechanisms which fulfils the essential biological requirements for hybrid development.
In India, pearl millet is cultivated in a total area of 6.93 million hectares with a production of 8.61 million tonnes and productivity of $1243 \mathrm{~kg} / \mathrm{ha}$ (Anonymous, 2019). It is the fifth most widely cultivated staple grain crop in India next to rice, wheat, maize and sorghum.

It is an outstanding multipurpose coarse cereal crop for grain, fodder and stover across wide range of environments around the world. It can adapt well to drought and adverse agroecological conditions, capable of rapid and vigorous growth, hence it is grown under 
marginal lands of low and erratic rainfall with high temperature and low soil fertility.

Pearl millet is rightly termed as poorman's food and nutri-cereal as it is a good source of carbohydrates $(67.1 \%)$, proteins $(11.6 \%)$, fat $(5.2 \%)$ and minerals $(2.7 \%)$. Protein content of pearl millet is higher than barley $(11.5 \%)$, maize $(11.1 \%)$, sorghum $(10.4 \%)$ and rice (7.2\%). It is having a low glycemic index, rich source of vitamins (thiamine, riboflavin and niacin) and minerals ( $\mathrm{P}, \mathrm{K}, \mathrm{Mg}, \mathrm{Fe}, \mathrm{Zn}$, $\mathrm{Cu}$ and $\mathrm{Mn}$ ). It supports weight loss and helps in reducing cholesterol levels (Pearl millet news, 2019).

Devolopment of superior hybrids mainly depends on nature and magnitude of genetic variability for different characters present in experimental material. Heritability measures the degree of resemblance between the parents and the off-springs, while genetic advance aids in exercising the necessary selection pressure. Heritability in conjunction with genetic advance has a major role in determining the effectiveness of selection for a character.

Hence in the present study a pool of maintainers (10) and restorers (27) were evaluated for presence of variability, heritability and expected genetic advance for various quantitative characters with a view to identify the parental lines with best potentiality for enhancing yield and its component characters.

\section{Materials and Methods}

Experimental material consisted of 10 maintainer (B) lines and 27 restorer (R) lines received from ICRISAT, Patancheru and were sown during summer, 2020 in a Randomized Block Design (RBD) with three replications at Agricultural Research Station, Perumallapalle, Tirupati, A.P.
Recommended package of practices were followed to raise the crop. Each germplasm line was sown in a single row of $5 \mathrm{~m}$ length with inter and intra row spacing of $45 \times 15$ $\mathrm{cm}$. The observations were recorded on plot basis for days to $50 \%$ flowering and days to maturity. Five plants were randomly selected from centre of row in each genotype of each replication and data was recorded for yield, yield attributing and water use efficiency traits viz., plant height $(\mathrm{cm})$, number of productive tillers per plant, panicle length $(\mathrm{cm})$, panicle girth $(\mathrm{cm})$, green fodder yield per plant $(\mathrm{g})$, dry fodder yield per plant $(\mathrm{g})$, panicle weight $(\mathrm{g}), 1000$ grain weight $(\mathrm{g})$, threshing $(\%)$, harvest index $(\%)$, grain yield per plant (g), SPAD chlorophyll meter reading at 45 DAS and specific leaf area at 45 DAS $\left(\mathrm{cm}^{2} \mathrm{~g}^{-1}\right)$.

The various genetic parameters viz., phenotypic coefficient of variation (PCV) and genotypic coefficient of variation (GCV), heritability $\left(\mathrm{h}_{\mathrm{bs}}^{2}\right)$ in broad sense and genetic advance as per cent of mean were calculated as suggested by Burton (1952), Lush (1940) and Johnson et al., (1955). The data analysis was carried out with WINDOWSTAT 9.2 software.

\section{Results and Discussion}

Analysis of variance revealed highly significant differences for all the characters under study, thereby indicating the presence of ample amount of genetic variation among the genotypes (Table 1). The estimates of variability parameters for yield and its component characters in 37 pearl millet inbred lines were presented in Table 2. Phenotypic coefficient of variation (PCV) was higher than genotypic coefficient of variation (GCV) for all the characters under study suggesting the role of environment in the expression of these characters (Fig. 1). 
High estimates of phenotypic and genotypic coefficient of variation were registered for grain yield per plant $(\mathrm{GCV}=51.48 \%$; $\mathrm{PCV}=$ $58.52 \%)$ followed by panicle weight $(\mathrm{GCV}=$ 42.97\%; PCV $=47.80 \%$ ), dry fodder yield per plant $(\mathrm{GCV}=42.04 \%$; $\mathrm{PCV}=49.14 \%)$, green fodder yield per plant $(\mathrm{GCV}=36.25 \%$; PCV $=42.18 \%$ ), number of productive tillers per plant $(\mathrm{GCV}=23.54 \%$; $\mathrm{PCV}=35.13 \%), 1000$ grain weight $(\mathrm{GCV}=22.62 \% ; \mathrm{PCV}=$ $23.95 \%)$, panicle length $(\mathrm{GCV}=21.40 \%$; $\mathrm{PCV}=23.87 \%)$ and harvest index $(\mathrm{GCV}=$ $21.34 \% ; \quad \mathrm{PCV}=26.60 \%$ ) indicating the existence of immense inherent variability that remained unaltered by environmental conditions among the genotypes, which in turn was more useful for exploitation in hybridization and/or selection.

Likewise, high estimates of variability were reported by Dehinwal et al., (2016), Nehra et al., (2017) and Talawar et al., (2017) for number of productive tillers per plant, 1000 grain weight and grain yield per plant;
Bhasker et al., (2017) and Kumar et al., (2014) for panicle length and dry fodder yield per plant; Vinodana et al., (2013) and Kumar et al., (2017) for green fodder yield per plant; Sumathi et al., (2010) and Vagadiya et al., (2013) for panicle weight which corroborates with the findings of the present study.

Moderate estimates of coefficient of variation were observed for plant height $(\mathrm{GCV}=$ $14.69 \%$; PCV $=17.13 \%$ ) followed by panicle girth $(\mathrm{GCV}=14.66 \% ; \mathrm{PCV}=17.09 \%)$, threshing percentage $(\mathrm{GCV}=12.02 \%$; $\mathrm{PCV}=$ $17.02 \%$ ), specific leaf area at 45 DAS (GCV $=11.32 \% ; \mathrm{PCV}=18.77 \%)$ and SPAD chlorophyll meter reading at 45 DAS (GCV = $10.35 \%$; PCV $=12.18 \%)$. This indicated the existence of sufficient variability for attempting selection to improve these traits in the genotypes studied. These findings were in consonance with Sathya et al., (2013) and Sowmiya et al., (2016) for both plant height and panicle girth and Priyanka (2019) for specific leaf area at 45 DAS.

Table.1 Analysis of variance for yield and yield attributes in 37 inbred lines of pearl millet

\begin{tabular}{|c|c|c|c|c|}
\hline \multirow[t]{2}{*}{ S. No. } & \multirow[t]{2}{*}{ Characters } & \multicolumn{3}{|c|}{ Mean sum of squares } \\
\hline & & $\begin{array}{l}\text { Replications } \\
\quad(\mathbf{d f}=2)\end{array}$ & $\begin{array}{l}\text { Treatments } \\
\quad(d f=36)\end{array}$ & $\begin{array}{c}\text { Error } \\
(\mathrm{df}=72)\end{array}$ \\
\hline 1 & Days to $50 \%$ flowering & 4.225 & $40.964 * *$ & 1.753 \\
\hline 2 & Days to maturity & 4.622 & $35.842 * *$ & 2.149 \\
\hline 3 & SPAD chlorophyll meter reading at 45 DAS & 25.680 & $73.938 * *$ & 8.398 \\
\hline 4 & Specific leaf area at 45 DAS $\left(\mathrm{cm}^{2} \mathrm{~g}^{-1}\right)$ & 2440.944 & $2445.743 * *$ & 900.872 \\
\hline 5 & Plant height $(\mathrm{cm})$ & 272.421 & $1434.744 * *$ & 153.430 \\
\hline 6 & Number of productive tillers per plant & 0.387 & $0.573 * *$ & 0.166 \\
\hline 7 & Panicle length $(\mathrm{cm})$ & 14.280 & $66.846^{* *}$ & 5.046 \\
\hline 8 & Panicle girth $(\mathrm{cm})$ & 0.085 & $0.345^{* *}$ & 0.037 \\
\hline 9 & Green fodder yield per plant $(\mathrm{g})$ & 1249.730 & $4012.531 * *$ & 423.272 \\
\hline 10 & Dry fodder yield per plant (g) & 52.680 & $361.445^{* *}$ & 39.331 \\
\hline 11 & Panicle weight (g) & 82.256 & $472.473 * *$ & 34.626 \\
\hline 12 & 1000 grain weight $(\mathrm{g})$ & 0.929 & $13.322 * *$ & 0.515 \\
\hline 13 & Threshing (\%) & 8.314 & $208.203 * *$ & 52.260 \\
\hline 14 & Harvest index (\%) & 22.276 & $167.086^{* *}$ & 26.047 \\
\hline 15 & Grain yield per plant $(\mathrm{g})$ & 48.215 & $264.725^{* *}$ & 23.514 \\
\hline
\end{tabular}

*Significant at 5\% level; ** Significant at $1 \%$ level 
Table.2 Estimates of mean, range and genetic parameters for yield and yield attributes in 37 inbred lines of pearl millet

\begin{tabular}{|c|c|c|c|c|c|c|c|c|c|c|c|}
\hline \multirow{2}{*}{$\begin{array}{l}\text { S. } \\
\text { No. }\end{array}$} & \multirow[t]{2}{*}{ Characters } & \multirow[t]{2}{*}{ Mean } & \multicolumn{2}{|c|}{ Range } & \multicolumn{2}{|c|}{ Variance } & \multicolumn{2}{|c|}{ Coefficient of Variation } & \multirow{2}{*}{$\begin{array}{c}\text { Heritability } \\
\text { (Broad sense) } \\
(\%)\end{array}$} & \multirow{2}{*}{$\begin{array}{l}\text { Genetic } \\
\text { advance } \\
\text { (GA) }\end{array}$} & \multirow{2}{*}{$\begin{array}{c}\text { Genetic } \\
\text { advance } \\
\text { as percent } \\
\text { of mean }(\%)\end{array}$} \\
\hline & & & Min. & Max. & Genotypic & Phenotypic & Genotypic & Phenotypic & & & \\
\hline 1. & Days to $50 \%$ flowering & 49.23 & 43.33 & 59.00 & 13.07 & 14.82 & 7.34 & 7.82 & 88.17 & 6.99 & 14.21 \\
\hline 2. & Days to maturity & 84.68 & 78.33 & 93.33 & 11.23 & 13.38 & 3.96 & 4.32 & 83.94 & 6.33 & 7.47 \\
\hline 3. & $\begin{array}{l}\text { SPAD chlorophyll meter reading } \\
\text { at } 45 \text { DAS }\end{array}$ & 45.15 & 33.07 & 53.93 & 21.85 & 30.24 & 10.35 & 12.18 & 72.23 & 8.18 & 18.12 \\
\hline 4. & $\begin{array}{l}\text { Specific leaf area at } 45 \text { DAS } \\
\left(\mathrm{cm}^{2} \mathrm{~g}^{-1}\right)\end{array}$ & 200.43 & 155.84 & 252.63 & 514.95 & 1415.82 & 11.32 & 18.77 & 36.37 & 28.19 & 14.07 \\
\hline 5. & Plant height $(\mathrm{cm})$ & 140.65 & 101.27 & 185.47 & 427.10 & 580.53 & 14.69 & 17.13 & 73.57 & 36.52 & 25.96 \\
\hline 6. & $\begin{array}{l}\text { Number of productive tillers per } \\
\text { plant }\end{array}$ & 1.56 & 1.00 & 2.67 & 0.14 & 0.30 & 23.54 & 35.13 & 44.92 & 0.51 & 32.51 \\
\hline 7. & Panicle length $(\mathrm{cm})$ & 21.21 & 13.87 & 33.07 & 20.60 & 25.65 & 21.40 & 23.87 & 80.32 & 8.38 & 39.50 \\
\hline 8. & Panicle girth $(\mathrm{cm})$ & 2.19 & 1.62 & 2.95 & 0.10 & 0.14 & 14.66 & 17.09 & 73.58 & 0.57 & 25.90 \\
\hline 9. & Green fodder yield per plant (g) & 95.41 & 32.93 & 197.20 & 1196.42 & 1619.70 & 36.25 & 42.18 & 73.87 & 61.24 & 64.19 \\
\hline 10. & Dry fodder yield per plant $(\mathrm{g})$ & 24.65 & 8.87 & 59.87 & 107.37 & 146.70 & 42.04 & 49.14 & 73.19 & 18.26 & 74.09 \\
\hline 11. & Panicle weight (g) & 28.11 & 10.40 & 73.27 & 145.94 & 180.58 & 42.97 & 47.80 & 80.83 & 22.37 & 79.58 \\
\hline 12. & 1000 grain weight $(\mathrm{g})$ & 9.13 & 4.55 & 14.96 & 4.27 & 4.78 & 22.62 & 23.95 & 89.23 & 4.02 & 44.02 \\
\hline 13. & Threshing (\%) & 59.99 & 32.87 & 69.65 & 51.98 & 104.24 & 12.02 & 17.02 & 49.87 & 10.49 & 17.48 \\
\hline 14. & Harvest index (\%) & 32.13 & 13.91 & 47.87 & 47.01 & 73.06 & 21.34 & 26.60 & 64.35 & 11.33 & 35.26 \\
\hline 15. & Grain yield per plant $(\mathrm{g})$ & 17.41 & 5.40 & 51.33 & 80.40 & 103.92 & 51.48 & 58.52 & 77.37 & 16.25 & 93.28 \\
\hline
\end{tabular}


Fig.1 Estimates of GCV and PCV for yield and yield attributes in pearl millet

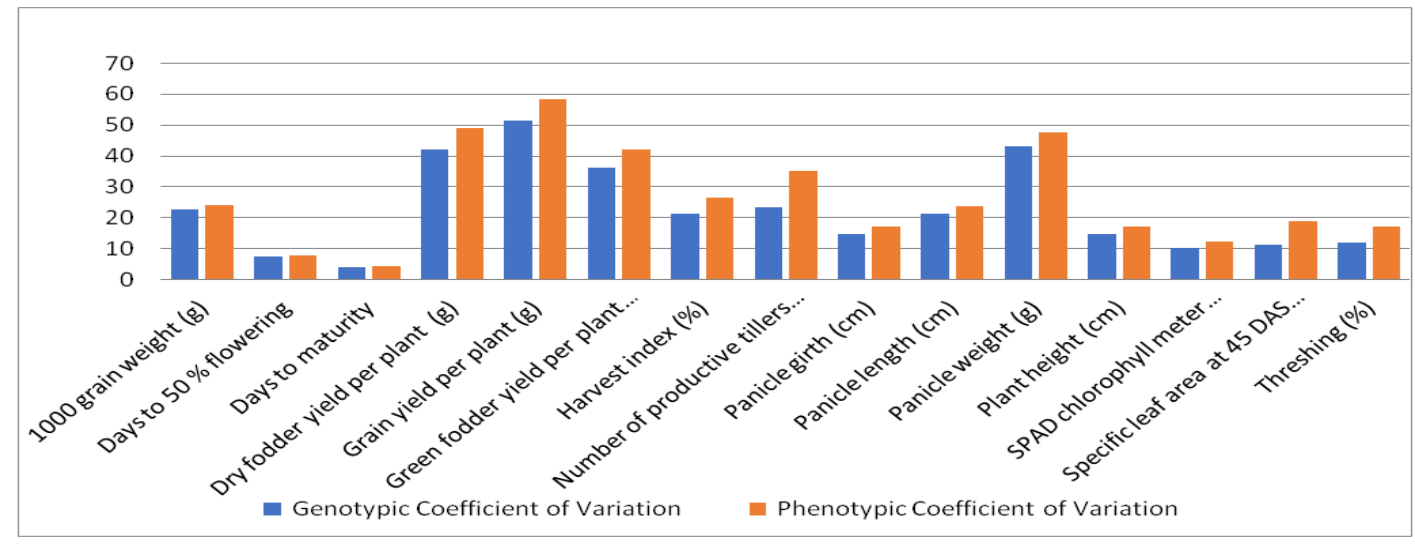

Fig.2 Heritability in broad sense and genetic advance as per cent of mean for yield and yield attributes in pearl millet



On contrary, low estimates of coefficients of variation were recorded for days to $50 \%$ flowering $(\mathrm{GCV}=7.34 \%$; $\mathrm{PCV}=7.82 \%)$ and days to maturity $(\mathrm{GCV}=3.96 \%$; $\mathrm{PCV}=$ $4.32 \%$ ) indicating narrow range of variability for these traits thereby restricting the scope for simple selection. Similar kind of low estimates of variability was also reported earlier by Bhasker et al., (2017) and Nehra et al., (2017) for days to 50\% flowering; Sharma et al., (2018) and Patel et al., (2019) for days to maturity.

Heritability is the heritable portion of phenotypic variance. Genetic advance gives an indication of expected genetic progress for a particular trait under suitable selection pressure. Heritability $\left(\mathrm{h}^{2}\right)$ coupled with genetic advance as per cent of mean (GAM) will bring out the genetic gain expected from selection than heritability alone in accurate prediction of the selection efforts (Johnson et al., 1955).

High heritability coupled with high genetic advance as per cent of mean were recorded for plant height $\left(\mathrm{h}^{2}{ }_{\mathrm{bs}}=73.57 \%\right.$; GAM $=$ $25.96 \%)$, panicle length $\left(\mathrm{h}_{\mathrm{bs}}^{2}=80.32 \%\right.$; GAM $=39.50 \%)$, panicle girth $\left(\mathrm{h}^{2}{ }_{\mathrm{bs}}=73.58 \%\right.$; GAM $=25.90 \%$ ), green fodder yield per plant $\left(\mathrm{h}^{2}{ }_{\mathrm{bs}}=73.87 \%\right.$; GAM $\left.=64.19 \%\right)$, dry fodder yield per plant $\left(\mathrm{h}^{2}{ }_{\mathrm{bs}}=73.19 \%\right.$; GAM $=$ 
$74.09 \%)$, panicle weight $\left(\mathrm{h}^{2}{ }_{\mathrm{bs}}=80.83 \%\right.$; $\mathrm{GAM}=79.58 \%), 1000$ grain weight $\left(\mathrm{h}^{2} \mathrm{bs}=\right.$ $89.23 \%$; GAM $=44.02 \%)$, harvest index $\left(\mathrm{h}^{2}{ }_{\mathrm{bs}}\right.$ $=64.35 \% ; \mathrm{GAM}=35.26 \%$ ) and grain yield per plant $\left(\mathrm{h}^{2}{ }_{\mathrm{bs}}=77.37 \%\right.$; GAM $\left.=93.28 \%\right)$ indicating the predominance of additive gene effects in controlling these traits. Early and simple selection could be exercised due to fixable additive gene effects.

These results are in line with findings of Bhasker et al., (2017) and Patel et al., (2019) for plant height, panicle length and dry fodder yield per plant; Talawar et al., (2017) and Kaushik et al., (2018) for 1000 grain weight and grain yield per plant; Bika and Shekawat (2015) and Singh et al., (2018) for panicle girth and green fodder yield per plant; Dehinwal et al., (2016) for panicle weight.

High heritability along with moderate genetic advance as per cent of mean recorded for days to $50 \%$ flowering $\left(\mathrm{h}^{2}{ }_{\text {bs }}=88.17 \%\right.$; $\mathrm{GAM}=$ $14.21 \%)$ and SPAD chlorophyll meter reading at 45 DAS $\left(h^{2}{ }_{b s}=72.23 \%\right.$; GAM $\left.=18.12 \%\right)$ indicated the presence of non-additive gene action. The high heritability is being exhibited due to favourable influence of environment rather than the genotype and selection for such traits may not be rewarding. These findings were supported by reports of Vinodana et al., (2013) and Bind et al., (2015) for days to $50 \%$ flowering. Whereas, high heritability in conjunction with low genetic advance as per cent of mean was observed for days to maturity $\left(\mathrm{h}^{2} \mathrm{bs}=83.94 \%\right.$; $\mathrm{GAM}=7.47 \%$ ) indicating the influence of dominant and epistatic genes in the inheritance and recurrent selection would be more effective to improve this character. Such confirmatory results were also given by Vidyadhar et al., (2007) and Yaqoob et al., (2015).

Moderate heritability coupled with moderate genetic advance as per cent of mean was registered for specific leaf area at 45 DAS $\left(\mathrm{h}^{2}{ }_{\mathrm{bs}}=36.37 \% ;\right.$ GAM $\left.=14.07 \%\right)$ and threshing percentage $\left(\mathrm{h}^{2}{ }_{\mathrm{bs}}=49.87 \%\right.$; GAM $=$ $17.48 \%$ ) which indicated the preponderance of non-additive gene action. Hence, it could be suggested that improvement of these characters might be difficult through simple selection.

Based on present study it can be concluded that the values of PCV were higher than GCV but in a narrow range for almost all the studied characters indicating the least influence of environment. The characters viz., plant height, panicle length, panicle girth, green fodder yield per plant, dry fodder yield per plant, panicle weight, 1000 grain weight, harvest index and grain yield per plant exhibited high heritability coupled with high genetic advance as per cent of mean indicating the role of additive gene action in governing these traits and direct selection would be rewarding for crop improvement.

\section{Acknowledgement}

The authors thank ICRISAT, Patancheru for providing the experimental material for present study and Acharya N.G. Ranga Agricultural University, Lam, Guntur for granting financial assistance and support in the conduct of experiment at ARS, Perumallapalle, Tirupati, A.P. This study is a part of M.Sc. student thesis work of first author.

\section{References}

Anonymous, 2019. Directorate of Economics and Statistics, Department of Agriculture, cooperation and Farmers Welfare, Ministry of Agriculture and Farmers Welfare, GOI. Agricultural statistics at a glance 2019. 56-58.

Bhasker, K., Shashibushan, D., Krishna, K.M and Bhave, M.H.V. 2017a. Genetic 
variability, heritability and genetic advance of grain yield in pearl millet [Pennisetum glaucum (L.) R. Br.]. International Journal of Pure and Applied Bioscience. 5(4): 1228-1231.

Bika, N.K and Shekawat, S.S. 2015. Genetic variability study in pearl millet [Pennisetum glaucum (L.) R. Br.] for green fodder yield and related traits. Electronic Journal of Plant Breeding. 6(2): 600-602.

Bind, H., Bharti, B., Kumar, S., Pandey, M.K., Kumar, D and Vishwakarma, D.N. 2015. Studies on genetic variability for fodder yield and its contributing characters in bajra [Pennisetum glaucum (L.) R. Br.]. Agricultural Science Digest. 35 (1): 78-80.

Burton, G.W. 1952. Quantitative inheritance in grasses. Proceedings of Sixth International Grassland Congress. 1: 277-283.

Dehinwal, A.K., Yadav, Y.P., Sivia, S.S and Kumar, A. 2016. Studies on genetic variability for different biometrical traits in pearl millet [Pennisetum glaucum (L.) R. Br.]. An International Quarterly Journal of Life Sciences. 11(2):1023-1026.

Johnson, H.W., Robinson, H.F and Comstock, R.E. 1955. Estimation of genetic and environmental variability in soybean. Agronomy Journal. 47: 314-318.

Kaushik, J., Vart, D., Kumar, M., Nehra, M and Kumar, R. 2018. Genetic diversity assessment of pearl millet maintainer lines. Journal of Pharmocognosy and Phytochemistry. 7(5): 2428-2432.

Kumar, S., Babu, C., Revathi S and Sumathi, P. 2017. Estimation of genetic variability, heritability and association of green fodder yield with contributing traits in fodder pearl millet [Pennisetum glaucum (L.) R. Br.]. International Journal of Advanced
Biological Research. 7(1): 119-126.

Kumar, Y., Lamba, R.A.S., Yadav, H.P., Kumar, R and Vart, D. 2014. Studies on variability and character association under rainfed conditions in pearl millet [Pennisetum glaucum (L.) R. Br.] hybrids. Forage research. 39(4): 175178.

Lush, J.L. 1940. Intra-sire correlation and regression of offspring in ramsasa method of estimating heritability of characters. Proceedings of American Society of Animal Production. 33: 292301.

Nehra, M., Kumar, M., Kaushik, J., Vart, D., Sharma, R.K and Punia, M.S. 2017. Genetic divergence, character association and path coefficient analysis for yield attributing traits in pearl millet [Pennisetum glaucum (L.) R. Br] inbreds. Chemical Science Review and Letters. 6(21): 538-543.

Patel, J.M., Patel, M.S., Soni, N.V., Patel, H.N and Prajapati, N.N. 2019. Genetic architecture of morpho-physiological traits over environments in pearl millet [Pennisetum glaucum (L.) R. Br.]. Electronic Journal of Plant Breeding. 10(1): 127-136.

Pearl millet news, 2018. ICAR - All India Coordinated Research project on pearl millet, Jodhpur, Rajasthan, India. http://www.aicpmip.res.in. 7: 1-12.

Priyanka, V. 2019. Genotype by trait analysis for yield, physiological and nutritional traits in pearl millet [Pennisetum glaucum (L.) R. Br.]. M.sc Thesis. ANGRAU, Guntur.

Sathya, M., Vinodhana, N.K and Sumathi, P. 2013. Heirarchial clustering of pearl millet [Pennisetum glaucum (L.) R. $\mathrm{Br}$.] inbreds for morpho-physiological traits. International Journal of Current Microbiology and Applied Sciences. 2(12): 647-652.

Sharma, B., Chugh, L.K., Sheoran, R.K., 
Singh, V.K and Sood, M. 2018. Study on genetic variability, heritability and correlation in pearl millets germplasm. Journal of Pharmacology and Phyto chemistry. 7(6): 1983-1987.

Singh, O.V., Gowthami, R., Singh, K and Shekhawat, N. 2018. Assessment of inter-character associations in the germplasm of pearl millet [Pennisetum glaucum (L.) R. Br.] over five years in hot arid climate of Rajasthan, India. International journal of Current Microbiology and Applied Sciences. 7(1): 3133-3149.

Sowmiya, P., Sumathi, P and Revathi, S. 2016. Estimates of genetic parameters and quantification of beta-carotene in pearl millet [Pennisetum glaucum L.] segregating population. Electronic Journal of Plant Breeding. 7(3): 640648.

Sumathi, P., Madineni, S and Veerabadhiran, P. 2010. Genetic variability for different biometrical traits in pearl millet [Pennisetum glaucum (L.) R. Br.] genotypes. Electronic Journal of Plant Breeding, 1(4): 437-440.

Talawar, A.M., Girish, G., Channabasavanna, A.S and Kitturmath, M.S. 2017. Studies on genetic variability, correlation and path analysis in pearl millet [Pennisetum glaucum (L). R. $\mathrm{Br}$.$] germplasm lines. Agricultural$ Science Digest. 37 (1): 75-77.

Vagadiya, K.J., Dhedhi, K.K and Joshi, H.J. 2013. Genetic variability, heritability, genetic advance of grain yield in pearl millet. Agricultural Science Digest. 33(3): 223-225.

Vidyadhar, B., Pooran, C and Swarnalatha, D.I. 2007. Genetic variability and character association for yield attributes in pearl millet (Pennisetum sp.) germplasm. Journal of Research. ANGRAU. 34(4): 114-117.

Vinodana, K.N., Sumathi, P and Sathya, M. 2013. Genetic variability and interrelationship among morpho-economic traits of pearl millet [Pennisetum glaucum (L.) R. Br.] and their implications in selection. International Journal of Plant, Animal and Environmental Sciences. 3(2): 145149.

Yaqoob, M. 2015. Genetic component analysis for yield and morphological traits in pearl millet [Pennisetum glaucum (L.) R. Br.] genotypes. Pakistan Journal of Scientific and Industrial Research. 58(3): 140-146.

\section{How to cite this article:}

Saikumar, P., M. Shanthi Priya, P. Shanthi and Latha, P. 2020. Genetic Variability Studies for Quantitative Traits in a Pool of Maintainer (B) and Restorer (R) Lines in Pearl Millet (Pennisetum glaucum (L.) R. Br.). Int.J.Curr.Microbiol.App.Sci. 9(12): 3234-3241. doi: https://doi.org/10.20546/ijcmas.2020.912.385 